\title{
Modified method of aerodynamic resistance calculation and its application to potential evapotranspiration estimation**
}

\author{
Marek Rodný1*, Reinhard Nolz², Viliam Novák , Hana Hlaváčiková1, Willibald Loiskandl2, \\ and Margarita Himmelbauer ${ }^{2}$ \\ ${ }^{1}$ Institute of Hydrology, Slovak Academy of Sciences, Dúbravská cesta 9, 84104 Bratislava, Slovak Republic \\ ${ }^{2}$ Institute of Hydraulics and Rural Water Management, University of Natural Resources and Life Sciences (BOKU), \\ Vienna, Muthgasse 18, 1190 Wien, Austria
}

Received December 14, 2015; accepted May 4, 2016

\begin{abstract}
A b s t r a c t. The aim of this study was to present and validate an alternative evapotranspiration calculation procedure that includes specific expression for the aerodynamic resistance. Calculated daily potential evapotranspiration totals were compared to the results of FAO56 procedure application and to the results of measurements taken with a precision weighing lysimeter permanently grown with irrigated, short grass. For the examination period from March 17 through October 31, 2011, it was found that daily potential evapotranspiration estimates obtained by both calculation procedures fitted well to the lysimeter measurements. Potential evapotranspiration daily totals calculated with the use of the proposed aerodynamic resistance calculation procedure gave better results for days with higher evapotranspiration, compared to the FAO56 method. The most important is that the approach based on the proposed alternative aerodynamic resistance could be effectively used even for a wide variety of crops, because it is not limited to any particular crop.

K e y w o r d s: potential evapotranspiration, reference evapotranspiration, grass, aerodynamic resistance, lysimeter
\end{abstract}

*Corresponding author e-mail: rodny@uh.savba.sk

**This work was partially supported by grant agency APVV, grant 0512-12, and by grant agency of the Slovak Academy of Sciences VEGA, projects 2/0032/13 and 2/0083/11. This publication is the result of the project implementation ITMS 26240120004, Centre of excellence for integrated flood protection of land, supported by the Research and Development Operational Programme funded by the ERDF.

\section{INTRODUCTION}

Proper evapotranspiration $(E)$ estimates are essential for energy and water balance studies, climate modelling, irrigation planning, quantification of agricultural production, and many other purposes (Gong et al., 2006; Pitman, 2003; Monteith and Unsworth, 1990; Sellers et al., 1997). Consequently, poor and non-representative evapotranspiration estimates could lead to misleading conclusions, with significant economic consequences (Allen et al., 2011).

Information about evapotranspiration can be obtained from a wide range of measurement systems, including weighing lysimeters, eddy covariance, Bowen ratio, and even satellite-based remote sensing. However, those measuring methods are usually complicated in application, the measuring equipment is expensive, and their results can differ considerably from each other. Therefore, several calculation procedures based on meteorological parameters have been proposed in literature (Allen et al., 1998; Hargreaves and Samani, 1985; Monteith 1965; Novák, 2012; Penman, 1948; Priestley and Taylor, 1972).

Penman (1948) defined the potential evapotranspiration $\left(E_{p}\right)$ as 'the amount of water transpired in a given time by a short green crop, completely shading the ground, of uniform height and with adequate water status in the soil profile'. The equation proposed by Penman is known as Penman equation. In this approach, the evapotranspiration rate was not related to any specific crop, and in fact there are many types of crops that fit into the description.

(C) 2016 Institute of Agrophysics, Polish Academy of Sciences 
Following the studies of Jensen et al. (1970), Doorenbos and Pruitt (1977), Perrier (1985) and Smith et al. (1992), the expert consultation recommended the concept of reference evapotranspiration $\left(E T_{o}\right)$ defined as the rate of evapotranspiration from a hypothetical reference crop with an assumed crop height of $0.12 \mathrm{~m}$, a fixed surface resistance $r_{c}=70 \mathrm{~s} \mathrm{~m}^{-1}$ and an albedo of 0.23 , closely resembling the evapotranspiration from an extensive surface of green grass of uniform height, actively growing, well-watered, and completely shading the ground'. Moreover, experts recommended the adoption of the Penman-Monteith equation (PM) for estimating $E T_{o}$ (Allen et al., 1998). The standardized procedure is described in detail in the FAO Irrigation and Drainage Paper No. 56 'Crop Evapotranspiration', generally referred to as the FAO56.

Once $E T_{o}$ is calculated, it can be further adjusted by an empirical crop coefficient $\left(K_{c}\right)$ to evaluate potential or actual crop evapotranspiration $\left(E T_{c}\right)$. Direct determination of $E T_{c}$ by the $P M$ equation is constrained by the need to determine the 'bulk' surface resistance $\left(r_{c}\right)$, the resistance to water vapour flow through the surface of the transpiring canopy.

Several approaches have been suggested for operational determination of the $r_{c}$ parameter, often recognized as a biophysical ET controller (Jarvis, 1976; Katerji and Rana, 2006; Lecina et al., 2003; Todorovic, 1999). However, presented formulas of $r_{c}$ calculation are valid for a particular canopy and location only (Katerji and Rana, 2011).

Another alternative modification to calculate potential evapotranspiration of different canopies was proposed by Novák and Hurtalová (1987), following studies of Budagovsky (1964) and Zilitikievich and Monin (1971). The potential evapotranspiration of well-watered canopy was calculated using the Penman-Monteith equation $(P M)$ (with $r_{c}=0$ ) and the aerodynamic resistance term $\left(r_{a}\right)$ expressed according to the modified approach of Zilitinkievich and Monin (1971). This approach, in principle, allows calculations of potential evapotranspiration $E_{p}$ also for non-reference, well watered canopies.

The aim of this study was:

- to present a calculation procedure of potential evapotranspiration of various canopies, using modified expression of the aerodynamic resistance to vapour flow, based on the proposal of Zilitinkievich and Monin (1971); and

- to compare the results of the proposed calculation procedure to the FAO56 method and to the results of weighing lysimeter measurements.

Close results of daily potential evapotranspiration totals $E_{p}$ estimated by both calculation procedures could lead to the development of a relatively simple procedure for the calculation of $E_{p}$ of various canopies.

\section{MATERIAL AND METHODS}

The FAO56 standardized procedure adopts the PenmanMonteith equation (Allen et al., 1998) in the following form:

$$
E=\frac{1}{\lambda} \frac{\Delta\left(R_{n}-G\right)+\rho_{a} c_{p} D / r_{a}}{\Delta+\gamma\left(1+r_{c} / r_{a}\right)},
$$

where: $E$ is the evapotranspiration $\left(\mathrm{mm} \mathrm{day}^{-1}\right), R_{n}$ is the net radiation at the evaporation surface level $\left(\mathrm{W} \mathrm{m}^{-2}\right), G$ is the soil heat flux $\left(\mathrm{W} \mathrm{m}^{-2}\right), \rho_{\mathrm{a}}$ is the mean air density at constant pressure $\left(\mathrm{kg} \mathrm{m}^{-3}\right), c_{p}$ is the specific heat of the air $\left(\mathrm{J} \mathrm{kg}^{-1}\right.$ $\left.\mathrm{C}^{-1}\right), r_{c}$ is the bulk canopy resistance $\left(\mathrm{s} \mathrm{m}^{-1}\right), r_{a}$ is the aerodynamic resistance $\left(\mathrm{s} \mathrm{m}^{-1}\right), \Delta$ is the slope of the saturation vapour pressure versus temperature relationship $\left(\mathrm{kPa}^{\circ} \mathrm{C}^{-1}\right)$, $D$ is the vapour pressure deficit of the air $(\mathrm{kPa}), \lambda$ is the latent heat of vaporisation $\left(\mathrm{J} \mathrm{kg}^{-1}\right)$, and $\gamma$ is the psychrometric constant $\left(\mathrm{kPa}^{\circ} \mathrm{K}^{-1}\right)$.

The aerodynamic resistance to water vapour flow in the FAO56 calculation procedure is expressed as:

$$
r_{a}=\frac{\ln \left[\frac{z_{m}-d_{e}}{z_{o m}}\right] \ln \left[\frac{z_{h}-d_{e}}{z_{o h}}\right]}{\kappa^{2} u_{z}},
$$

where: $z_{m}, z_{h}$ are the heights of the wind speed and air temperature measurements $(\mathrm{m}), d_{e}$ is the zero plane displacement height (m) estimated by $d_{e}=0.67 \mathrm{~h}$, where $h_{c}$ means the height of the crop (m); $z_{o h}$ is the roughness length governing the transport of the and vapour $(\mathrm{m}), z_{\text {om }}$ is the roughness length governing momentum transfer $(\mathrm{m})$, $u_{z}$ is the wind velocity at height $z\left(\mathrm{~m} \mathrm{~s}^{-1}\right)$, and $\kappa$ is the von Karman constant $(-), \kappa=0.41$ was used in this study.

The applicability of the Penman-Monteith Eq. (1) is strongly limited by the knowledge of bulk canopy resistance $r_{c}$ which depends on canopy properties as well as on leaf water potential. Bulk canopy resistance is characteristic for a particular canopy under particular conditions, and its application to other conditions is not recommended (Jarvis, 1976; Katerji and Rana, 2006). Another possibility to calculate potential evapotranspiration is set $r_{c}=0$, ie evapotranspiration from wet canopy is assumed. Aerodynamic resistance is denoted as $r_{a}$. Then, the Penman-Monteith equation can be expressed in the form:

$$
E_{p}=\frac{1}{\lambda} \frac{\Delta\left(R_{n}-G\right)+\rho_{a} c_{p} D / r_{a-e}}{\Delta+\gamma} .
$$

Based on the Bowen ratio measurements above the grass canopy, Zilitikievich and Monin (1971), and Budagovsky (1981), expressed normalized distribution of air humidity, air temperature and wind velocity in sublayers $\left(0, z_{o}\right)$ and $\left(z_{o}, z\right)$. Based on those distributions, the aerodynamic resistance to water vapour transport was expressed as a sum 
of resistances characterizing two horizontal air layers embracing the height intervals $\left(0, z_{o}\right)$ and $\left(z_{o}, z\right)$. In this concept, the evaporation starts directly at the evaporating surface $(z=0)$ and not at the height characterized by the roughness length $\left(z_{o}\right)$, which is in contrast with the FAO56 methodology. The evaporating surface is assumed to be at the 'effective height of the canopy' or the 'zero displacement level', which means the same height. This approach (as well as Penman, 1948) characterizes evapotranspiration from wet surface.

For the equilibrium state of the atmosphere, the aerodynamic resistance to water vapour transport in the viscous sublayer, defined by the height interval $\left(0, z_{o}\right)$, can be evaluated using the empirical form relating the aerodynamic resistance to the Reynolds number (Zilitikievich and Monin, 1971). The generalized equation for the lower sublayer $\left(0, z_{o}\right)$ can be expressed in the following form:

$$
r_{a_{-} s u b}=\frac{\left(\frac{z_{o} u_{*}}{v_{a}}\right)^{p_{e}}}{\kappa u_{*}},
$$

where: $u_{*}$ is the friction velocity $\left(\mathrm{m} \mathrm{s}^{-1}\right), z_{o}$ is the crop specific roughness length of the evaporating surface $(\mathrm{m}), v_{a}$ is the kinematic viscosity of the air $\left(\mathrm{m}^{2} \mathrm{~s}^{-1}\right)$, and $p_{e}$ is an empirical parameter, slightly dependent on canopy properties and on the state of the atmosphere. Zilitinkievic and Monin (1971) use a constant value close to $0.5(-), p_{e}=0.45$ was used in this study. Expressions for friction velocities together with the crop specific roughness lengths could be found in the monograph by Novák (2012).

The resistance to water vapour transport in the boundary layer above the canopy, defined by the height interval $\left(z_{o}, z\right)$, can be evaluated using the empirical form suggested by Thom $(1972,1975)$. When assuming the roughness length parameters for transport of heat $\left(z_{\text {oh }}\right)$ and momentum $\left(z_{o m}\right)$ equal $\left(z_{o m}=z_{o h}\right)$, it can be assigned as $z_{o}$; the resistance in the boundary layer $\left(z_{o}, z\right)$ can be expressed in the following form:

$$
r_{a_{-} b}=\frac{\ln \left(\frac{z-d_{e}}{z_{o}}\right)}{\kappa u_{*}},
$$

where: $z$ is the height of wind velocity measurements, $d_{e}$ is the zero plane displacement height (m).

Alternatively, the specific expression of the aerodynamic resistance $\left(r_{a}\right)$ of the layer $(0, z)$, that combines the aerodynamic resistance to water vapour transport in the sublayer $\left(z_{o}, z\right)$ and in the boundary layer just above the canopy $\left(0, z_{o}\right)$, can be expressed in the form:

$$
r_{a_{-} e}=\frac{\left(\frac{z_{o} u_{*}}{v_{a}}\right)^{p_{e}}+\ln \left(\frac{z_{2}-d_{e}}{z_{o}}\right)}{\kappa u_{*}} .
$$

The parameters are the same as described above (ie Eqs 4 and 5). Roughness lengths in Eq. (6) are $z_{o}$ which is the roughness length governing the momentum transport (it can be estimated from wind velocity profiles). As it was mentioned, for neutral state of the atmosphere $p_{e}=0.45$ is a good approximation.

Reference evapotranspiration was measured by means of a weighing lysimeter facility at the experimental site of the University of Natural Resources and Life Sciences, Vienna (BOKU). The experimental site is located in Gross-Enzersdorf $\left(48^{\circ} 12^{\prime} \mathrm{N}, 16^{\circ} 34^{\prime} \mathrm{E} ; 157 \mathrm{~m}\right.$ a.s.1.) in the north-eastern part of Austria. The lysimeter surface and its surroundings are grown with grass that is cut and irrigated frequently. The main part of the lysimeter facility consists of a cylindrical vessel with an inner diameter of $1.9 \mathrm{~m}$ (surface area $A=2.85 \mathrm{~m}^{2}$ ) and a hemispherical bottom with a maximum depth of $2.5 \mathrm{~m}$, packed with sandy loam soil $(0-140 \mathrm{~cm})$ over gravel $(140-250 \mathrm{~cm})$ (Neuwirthand Mottl, 1983). A mechanical weighing system transmits a fractional amount of the lysimeter mass to an electronic load cell. The analogue output signal of the load cell is amplified and converted to digital units (Nolz et al., 2011). Weighing data are measured every few seconds, averaged and stored every $10 \mathrm{~min}$. As a consequence, changes of water mass in the lysimeter $\left(\Delta W_{l y s}\right)$ can be determined for a certain time interval. During dry spells, the lysimeter is additionally irrigated to meet the grass maximum water requirements (Nolz et al., 2013).

Meteorological parameters for evapotranspiration calculations were obtained from the on-site standard reference weather station of the Central Institute for Meteorology and Geodynamics, Austria (ZAMG), the standard type instruments of which are situated nearby the lysimeter. Details can be found in a paper of Nolz et al. (2013). The meteorological parameters measured included solar radiation $R_{s}$ $\left(\mathrm{MJ} \mathrm{m}^{-2} \mathrm{~h}^{-1}\right)$, maximum and minimum air temperatures at $2 \mathrm{~m}$ height $T_{\max } T_{\min }\left({ }^{\circ} \mathrm{C}\right)$, relative humidity at $2 \mathrm{~m}$ height $r(\%)$, wind velocity at $10 \mathrm{~m}$ height $u_{10}\left(\mathrm{~m} \mathrm{~s}^{-1}\right)$, and precipitation $P(\mathrm{~mm})$. The wind velocity at $2 \mathrm{~m}$ height was determined using the wind profile relationship as presented in Allen et al. (1998). Net radiation $\left(R_{n}\right)$ was determined from the measured solar radiation $\left(R_{s}\right)$ according to Allen et al. (1998), and used in both calculation procedures. Experimental data available for this study were collected from the 17th of March through the 31st of October, 2011.

\section{RESULTS AND DISCUSSION}

The method of FAO56 (Allen et al., 1998) allows to calculate the reference evapotranspiration and then to calculate potential evapotranspiration of various canopies using their crop coefficient.

The method proposed aims to calculate potential evapotranspiration of various canopies without knowing the 'bulk' canopy resistance $r_{c}$ (Eq. (1)) which is difficult to 
obtain (Jarvis, 1976). Then, it is assumed that $r_{c}=0$, valid for wet surfaces. Differences in the values of $r_{c}$ could lead to differences in $E_{p}$, therefore it was necessary to check it by comparing the results of both calculation methods and the results of the lysimetric measurements, as well as to evaluate the differences. The close results of the measured and calculated daily potential evapotranspiration totals of grass showed that the differences were small and acceptable. Hence, it follows that the proposed method could be acceptable for the calculation of potential evapotranspiration of various canopies.

Daily reference evapotranspiration was calculated using Eq. (1) with aerodynamic resistances expressed by Eq. (2). The potential evapotranspiration of wet grass canopy was calculated using Eq. (3), with aerodynamic resistances expressed by Eq. (6). Comparisons of the daily evapotranspiration totals calculated by both procedures to the evapotranspiration of irrigated grass measured by means of the lysimeter are presented in Figs 1 and 2.

As it is shown in Figs 1 and 2, both calculation procedures gave estimates of evapotranspiration daily totals which fit well to the data obtained from the lysimeter. While the FAO56 method slightly outperformed the proposed method during days with high evapotranspiration, the opposite was true for days with low evapotranspiration. Due to this, more significant scatter and a slightly lower coefficient of determination were obtained for the FAO56 method (Figs 1 and 2).

The presented results indicated that the scatter of the average daily values of $E T_{o}$ calculated by FAO56 and by the proposed method depend slightly on the prevailing meteorological conditions. The scatter of the calculated evapotranspiration daily totals (Fig. 1) is more pronounced during days with higher air temperatures (higher radiation

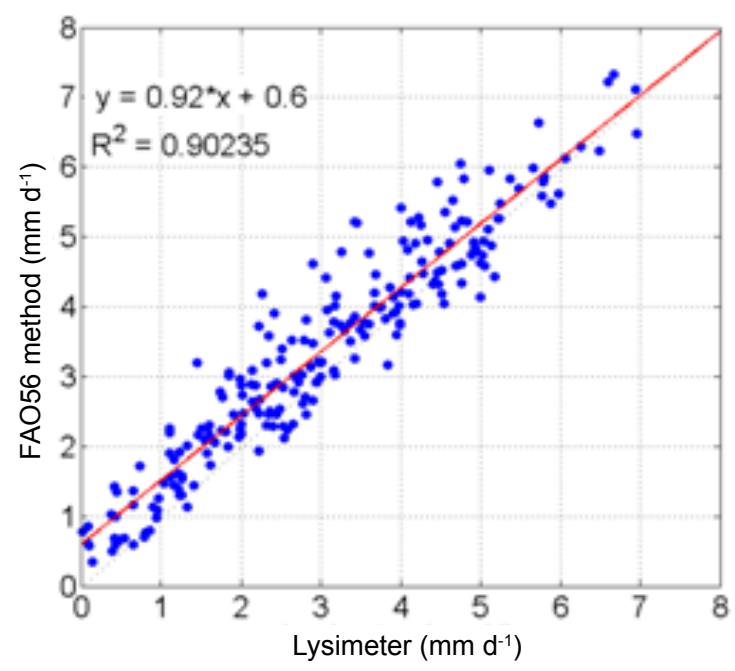

Fig. 1. Daily reference evapotranspiration $E T_{o}$ during the growing season, calculated by the FAO56 procedure, and daily evapotranspiration of irrigated grass measured by means of the weighing lysimeter.

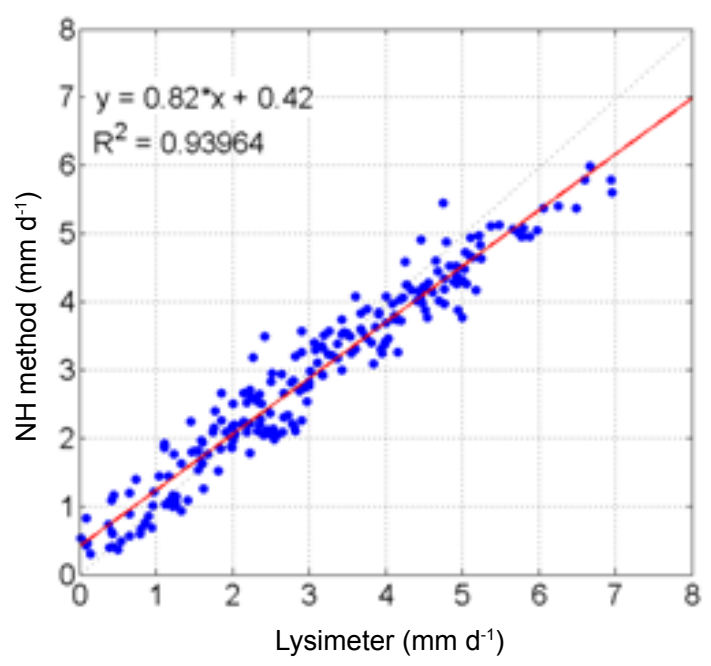

Fig. 2. Daily potential evapotranspiration $E_{p}$ during the growing season, calculated by the proposed procedure, and evapotranspiration of irrigated grass measured by means of the weighing lysimeter.

terms), when calculated by the FAO56 method, in comparison to the proposed method using aerodynamic resistance term (Fig. 2). Therefore, this indicates a superiority of the proposed procedure for the calculation of daily reference evapotranspiration totals over the FAO56 method. It can be mentioned that all the methods of evapotranspiration calculation are approximate, ie some differences between measured and calculated data are expected. The main reasons are the difficulties with the estimation of adequate input data, characterizing the system, but even the method of aerodynamic resistance calculation can be important.

It was shown in this study that the FAO56 method and the proposed one can give close results, comparable to the results of lysimetric measurements of well-watered grass canopy evapotranspiration. This demonstrates the applicability of the proposed method to calculate potential evapotranspiration of a wide variety of crops. Moreover, the applicability of the proposed method is not limited by the knowledge of the canopy resistance, which could considerably simplify potential evapotranspiration calculation procedure also for the non-reference canopies. This needs further research, which is complicated by the lack of measurement results for non-referenced canopies.

\section{CONCLUSIONS}

1. The results of two potential evapotranspiration calculation procedures (FAO56 and the proposed one) were analyzed, and daily totals of potential evapotranspiration were calculated and compared to the evapotranspiration of irrigated grass of the weighing lysimeter facility.

2. It was shown that daily reference (potential) evapotranspiration of grass canopy estimates by FAO56 and by the proposed method were close to the lysimeter values, but the proposed modified method gave values closer to the 
measured ones. The proposed method, based on using the modified aerodynamic resistance calculation, can be used, in principle, even for non-reference canopies; this is the main advantage of the proposed procedure.

3. The application of the FAO56 method for nonreference canopies remains complicated due to the tedious determination of the surface resistance parameters. The results indicate that this problem could be partly resolved using the proposed approach.

\section{REFERENCES}

Allen R.G., Pereira L.S., Howell T.A., and Jensen M.E., 2011. Evapotranspiration information reporting: I. Factors governing measurement accuracy. Agric. Water Manag., 98, 899-920.

Allen R.G., Pereira L.S., Raes D., and Smith M., 1998. Crop evapotranspiration: guidelines for computing crop water requirements. FAO Irrigation and Drainage Paper No. 56, FAO, Rome.

Budagovsky A.I., 1964. Evaporation of Soil Water (in Russian). Nauka Press, Moskva, Russia.

Budagovsky A.I., 1981. Soil water evaporation. In: Physics of Soil Water (in Russian). Nauka Press, Moskva, Russia.

Doorenbos J. and Pruitt W.O., 1977. Guidelines for predicting crop-water requirements. In: FAO Irrigation and Drainage Paper No. 24, FAO, Rome, Italy.

Gong L., Xu C., Chen D., Halldin S., and Chen Y.D., 2006. Sensitivity of the Penman-Monteith reference evapotranspiration to key climatic variables in the Changjiang (Yangtze River) basin. J. Hydrol., 329, 620-629.

Hargreaves G.H. and Samani Z.A., 1985. Reference crop evapotranspiration from temperature. Appl. Eng. Agric., 1, 96-99.

Jarvis P.G., 1976. The interpretation of the variations in leaf water potential and stomatal conductance found in canopies in the field. Phil. Trans. R. Soc. London, B, 273, 595-610.

Jensen M.E., Robb D.C.N., and Franzoy C.E., 1970. Scheduling irrigations using climate-crop-soil data. J. Irrig. Drain. Div. ASCE, 96, 25-38.

Katerji N. and Rana G., 2006. Modelling evapotranspiration of six irrigated crops under Mediterranean climate conditions. Agric. Forest Meteorol., 138, 142-155.

Katerji N. and Rana G., 2011. Crop reference evapotranspiration: a discussion of the concept, analysis of the process and validation. Water Resour. Manag., 25, 1581-1600.

Lecina S., Martinez-Cob A., Perez P.J., Villalobos F.J., and Baselga J.J., 2003. Fixed versus variable bulk canopy resistance for reference evapotranspiration estimation using the Penman-Monteith equation under semiarid conditions. Agric. Water Manag., 60, 181-198.

Monteith J.L., 1965. Evaporation and environment. In: Symp. Society Experimental Biology, The State and Movement of Water in Living Organisms (Ed. G.E. Fogg). Academic Press, Inc., NY.
Monteith J.L. and Unsworth M.H. 1990. Principles of environmental physics. London, Edward Arnold, UK.

Neuwirth F. and Mottl W., 1983. Lysimeter at the Agrometeorological Station at Groß-Enzersdorf (in German). Wetter und Leben, 35, 48-53.

Nolz R., Kammerer G., and Cepuder P., 2011. Data management of the weighing lysimeter in Groß-Enzersdorf (Ed. LFZ Raumberg-Gumpenstein) (in German). In: Proc. 14th Lysimeter Conf., May 3-4, Gumpenstein, Austria.

Nolz R., Kammerer G., and Cepuder P., 2013. Interpretation of lysimeter weighing data affected by wind. J. Plant Nutr. Soil Sci., 176, 200-208.

Novák V., 2012. Evapotranspiration in the Soil-Plant-Atmosphere System. Springer Sci. Business Media, Doordrecht, Holland.

Novák V. and Hurtalová T., 1987. Velocity coefficient of turbulent transport and its use for potential evapotranspiration estimation (in Slovak). Vodohosp. Čas., 35, 3-21.

Penman H.L., 1948. Natural evaporation from open water, bare soil and grass. Proc. R. Soc. London, 193, 120-146.

Perrier A., 1985. Updated evapotranspiration and crop water requirement defini-tions (Eds A. Perrier, C. Riou). In: Crop Water Requirements (ICID Int. Conf.). INRA, Paris, France.

Pitman A.J., 2003. The evolution of, and revolution in, land surface schemes designed for climate models. Int. J. Climatol., 23, 479-510.

Priestley C.H.B. and Taylor R.J., 1972. On the assessment of surface heat flux and evaporation using large scale parameters. Mon. Weather Rev., 100, 81-92.

Sellers P.J., Dickinson R.E., Randall D.A., 1997. Modeling the exchanges of energy, water, and carbon between continents and the atmosphere. Science, 275, 502-509.

Smith M., 1992. CROPWAT a computer programme for irrigation planning and management. In: FAO Irrigation and Drainage Paper No.46. FAO, Rome, Italy, downloadable on http://www.fao.org/nr/water/infores_databases_cropwat. html, (Version 8.0 of 2008).

Thom A.S., 1972. Momentum, mass and heat exchange of vegetation. Quarterly J. Royal Meteorol. Soc., 98. 124-134.

Thom A.S., 1975. Momentum, mass and heat exchange of vegetation. Vegetation and the atmosphere (Ed. J.L. Monteith). Academic, London, I, 57-109.

Todorovic M., 1999. Single-layer evapotranspiration model with variable canopy resistance. J. Irrig. Drain. Eng., 125(5), 235-245.

Zilitinkevich S.S. and Monin A.S., 1971. Turbulence in Dynamic Models of the Atmosphere (in Russian). Nauka Press, Leningrad, Russia. 